\title{
ISSUES ON RESTRUCTURING OF A FINANCING FACILITY IN MALAYSIAN ISLAMIC BANKS
}

\author{
Abdul Muneem ${ }^{1}$ \\ Nor Fahimah Mohd Razif ${ }^{2}$ \\ Abdul Karim Ali ${ }^{3}$
}

\begin{abstract}
The restructuring of a financing facility in Malaysian Islamic banks provides assistance to customers facing financial hardships. However, the facility arises some Shari' ah concerns like qalb aldayn (debt restructuring), imposing new selling price and profit, and using a current asset for new contracts. The research aims to examine the current practice of restructuring of financing facilities and to identify the issues and challenges in this facility in Malaysian Islamic banking institutions. To fulfill the objectives of this research, a qualitative approach is adopted to achieve the theoretical background of the study and interviews conducted to obtain practical views of the subject matter. The study finds that the increase in a new contract over the existing contract generates ribā. In addition, the ownership of the commodity has to be transferred in a new contract to conclude a contract, however, the ownership is not transferred in the practice of restructuring of financing facility. Finally, the restructuring of a financing facility is similar to qalb al-dayn which is non-Shari 'ah compliant according to the majority of scholars. The study
\end{abstract}

1 Postgraduate Student, Department of Fiqh and Usul, Academy of Islamic Studies, University of Malaya, 50603, Kuala Lumpur, Malaysia, a.muneem@yahoo.com

2 Senior Lecturer, Department of Fiqh and Usul, Academy of Islamic Studies, University of Malaya, 50603, Kuala Lumpur, Malaysia, norfahimah@um.edu.my

3 Associate Professor, Department of Fiqh and Usul, Academy of Islamic Studies, University of Malaya, 50603, Kuala Lumpur, Malaysia, abdkarim@um.edu.my 
suggests resolving those issues before offering such a facility to the customers will not result in non-Sharì ah compliant issue and alternatively, the Islamic banks may offer rescheduling of financing facility instead of restructuring.

Keywords: restructuring of financing facility, Islamic banking, qalb al-dayn, Sharīah

\section{INTRODUCTION}

Islamic banks in Malaysia are providing various types of financing products to cater both individual needs and corporate demands throughout the country. The financing facilities provided are based on Shari' ah concepts, to name a few: murābahah, tawarruq, and ijärah. The Sharī'ah concepts recognized in these products allow beneficiaries to pay back their obligation within an agreed stipulated time period i.e. monthly installment.

There are unavoidable situations, typically due to financial constraints, impeding customers to fulfil their obligation. To assist these customers in dire need, Islamic banks are providing rescheduling or restructuring of their existing financing facilities. By opting for the facility, customers have to pay lesser in monthly repayment, in return, the financing tenure is extended. However, this facility of debt rescheduling has led to many changes and issues that should be addressed before being offered to potential prospects. Therefore, the study will demonstrate, at length, how it is practiced in Malaysian Islamic banks.

The first objective of this research is to examine the current practice of restructuring of financing facility in Islamic banks in Malaysia. The second objective is to identify issues and challenges in the restructuring application in Islamic banks in Malaysia. It is important to mention that these issues are critical in nature and require extensive study in reaching a solid resolution prior to allowing customers to enjoy the perks of the product.

\section{LITERATURE REVIEW}

The literature on restructuring of financing facilities in Islamic financial institutions has been performed through various sources of knowledge such as books, journals, conference papers and theses and dissertations. 
The earliest literature on the issue of qalb al-dayn is addressed by Hammād ${ }^{4}$ who is a contemporary scholar of Islamic banking and finance. His study covers the originality of qalb al-dayn from classical scholars and its practices in the era of ignorance (ayyām al-jāhiliyyah). The author explains five forms of qalb al-dayn mentioning their rules from the scholars' views. He also suggests some alternatives to the practice of qalb al-dayn for the modern Islamic banking industry. He concludes that because of the delay of the payments by the customers results to some difficulties in providing the promised profit to the investors by the Islamic banks.

The current practice of restructuring of financing facilities in Islamic banks and its possible Sharī'ah issues were slightly mentioned by Siti Mazlita Yamaludin 5 and Nasrun Mohamad ${ }^{6}$ in their study. Siti Mazlita Yamaludin focuses on murābahah contract and its recovery system where she also highlights the issue of restructuring of financing facility through murābahah contract. Similarly, Nasrun Mohamad also studies tawarruq and its application in Malaysian Islamic financial institutions where he addresses the issues of restructuring of financing facility through tawarruq contract. Both studies find that the additional amount in order to restructure a facility leads to Sharī ah issue.

Mohd Johan Lee $^{7}$ studies the recovery system of Islamic finance, rescheduling and restructuring of financing facilities from legal perspective. His study provides significant information regarding the practice of those facilities and their structure and legal issues. Even though his study does not cover Sharī'ah issues explicitly, but it assists to extract some Sharī'ah issues based on the structure and practices mentioned.

4 Hammād, Nazih "Qalb Al-Dayn Wa Al-Ahkām Al-Fiqhiyyah Al-Muta'alliqah Bihi Fi Al-Fiqh Al-Islāmī." Majallah al- 'Adl, Wazārah al- 'Adl al-Sa 'ūdiyyah, no. 31 (2006): 47-72. The author revised the paper and presented it in the conference "4th Fiqh Conference for Islamic Finance Institutions, 2011" with the title: "Qalb al-Dayn: Șuwaruhu, wa Aḥkāmuhu wa Badā iluhu al-Shar 'iyyah fi Mu 'àmalāt alMașārif al-Islāmiyyah al-Mu 'ạșirah"

5 Siti Mazlita Yamaludin, 'Recovery Process of Murabahah Financing in Islamic Financial institutions in Malaysia,' (Master's Dissertation, International Islamic University Malaysia, Malaysia, 2014).

6 Nasrun Mohamad@Ghazali, 'Tawarruq in Malaysian Financing System: A Case Study on Commodity Murabahah Product at Maybank Islamic Berhad' (Master's Dissertation, University of Malaya, Kuala Lumpur, 2014).

7 Mohd Johan Lee, Islamic Finance Recovery, Rescheduling and Restructuring of Islamic Financing Facilities (Selangor: LexisNexis Malaysia Sdn. Bhd., 2016). 
Nāṣir Ibn 'Abd al-Raḥmān al-Dawūd ${ }^{8}$ discusses about restructuring of financing facilities and its similar practices in the banking system. The author also highlights the relation of qalb al-dayn with restructuring of financing facilities and explains the Shari'ah rules for qalb al-dayn based on the classical scholars' views. In addition, the author provides some alternatives of restructuring of financing facilities mentioning the conflicts of scholars and Sharī'ah barriers in implementing them.

Finally, Aznan Hasan et al. ${ }^{9}$ address debt rescheduling and restructuring of financing facilities in their paper. The study includes the opinions of the Shari' ah scholars regarding qalb al-dayn. The authors suggest some alternatives for the payment of debt for financing facilities provided by the Islamic banks such as maturity extension, haircut, converting debt into salam capital, sale with the condition to purchase, conclusion of new murābahah using the proceed to settle the existing debt, renewal of ijārah contract by increasing the amount of rental, converting debt into mudārabah capital and debt to equity swap. Moreover, the research also recommends some Sharī'ah parameters in order to adopt rescheduling and restructuring of financing facilities in Islamic banks. Some of the significance parameters are:

a) The two contracts (existing financing facility and the new facility) should be separated.

b) The new contract (for the financing facility) should not stipulate to settle the existing contract i.e. the existing debt.

c) The debtor should entertain freely the proceeds of a new contract without any conditions.

Based on the above literature, it can be concluded that most of the studies cover the concept of qalb al-dayn and restructuring of financing facilities and provide some alternatives to the facility. However, it should be noted that

8 Nāṣir Ibn 'Abd al-Raḥmān al-Dawūd, 'I'ādah al-Tamwīl,' in AAOIFI 15th Annual Sharī'ah Boards Conference, Manama, Kingdom of Bahrain: AAOIFI, 2017).

9 Aznan Hasan, Muhamad Nasir Haron, and Mohd Faysal. "Rescheduling, Refinancing, and Restructuring of Islamic Financing Facilities from the Sharī'ah Perspective." Paper presented in 10th Muzakarah Cendekiawan Sharī' ah Nusantara -the Regional Sharī'ah Scholar Dialogue, International Sharī' ah Research Academy for Islamic Finance (ISRA), Kuala Lumpur, Malaysia, 1-2 June 2016. The paper was later revised by the authors. See: Aznan Hasan, Muhamad Nasir Haron, Mohd Faysal Mohammed, and Budeeman Mana, 'Rescheduling and Restructuring of Islamic Financing Facilities: A Sharī'ah Perspective,' ISRA Research Paper, no. 100 (Malaysia: International Sharī'ah Research Academy of Islamic Finance (ISRA), 2018). 
the previous study includes the overall practice of restructuring of financing facilities where this study focuses on two specific Islamic banks through indepth interviews with the respective practitioners. In addition, this research also addresses the issues and challenges for the practice of restructuring of financing facilities in Malaysian Islamic banks.

\section{METHODOLOGY}

The paper adopts the qualitative research approach to meet the objectives of this research. Generally, the qualitative research approach is used when the research intends to explain a situation, problem, occasion or phenomenon of something. ${ }^{10}$ The reason of adopting qualitative approach for this research is because it explains and examines the practice of restructuring of financing facilities in Malaysia and addresses the issues and challenges of practicing of such facility. Moreover, to investigate the practice of restructuring facility in Islamic banks, the study conducted two semi-structured interviews from two domestic Islamic banks. Two banks were chosen based on the concept that one of them is under a full-fledged Islamic financing group and the other one is an arm of a group which provide also conventional financing. Moreover, both interviewees have more than 10 years of experience in the respective field.

\section{THE CONCEPT OF RESTRUCTURING OF A FINANCING FACILITY IN ISLAMIC BANKING}

Islamic banking offers lucrative financing facilities designed for individual essentials as well as corporate customers. When customers agree to commit in a contract allocated under a Sharī ah compliant scheme, they have tied an obligation to pay back their creditors. It is expected in Sharī ${ }^{`}$ ah for beneficiaries to abide by what they have agreed upon that is payment during specific time periods. However, if customers encounter financial difficulties in carrying out their obligation despite giving their promise, one of the ways out might be seeking help from the bank. To cater this specific type of need, the bank may offer a choice to restructure the facility whilst sustaining the financing and maintaining the business.

10 Ranjit Kumar, Research Methodology: A step-by-step guide for beginners (London: Sage Publications Ltd., 1999). 


\section{Restructuring of a Financing Facility in Banking Institutions}

Restructuring of a financing facility is offered by both Islamic banks and conventional banks alike. However, in conventional banks, besides offering restructuring facility, there are some other facilities namely loan top-up, bridge financing, and rollover.

The International Monetary Fund explains debt restructuring as "debt reorganization or debt refinancing arises from bilateral arrangements involving both the creditor and the debtor that alter the terms established for the servicing of a debt". ${ }^{11}$ Similarly, Maybank Malaysia Berhad describes debt restructuring as "the modification of the principal terms and conditions of the facility, which includes a change in the type or structure of the facilities or change to its terms, e.g. conversion of Overdraft to Term Loan. However, costs will be incurred in terms of administrative and legal documentation". ${ }^{12}$

\section{Restructuring of a Financing Facility from the Sharī ah Perspective}

Aznan et al. explain that debt restructuring is similar to debt refinancing as both mechanisms would result in the termination of existing contracts and execution of new ones with a new financing amount in a more extended tenure. ${ }^{13}$ Further elaborated by Abdullah and Ramli, in financing restructuring, the terms and conditions have been modified completely. In assisting customers to overcome their financial distress in a short-term period whilst prolonging the business prospect's longevity, the modification may change the type or structure of the

11 International Monetary Fund (IMF), 'External Debt Statistics: Guide for Compilers and Users,' (USA: IMF, 2014), 89, http://www.tffs.org/pdf/edsg/ft2014.pdf, 28 November 2018.

12 Maybank, '3R Campaign - Reschedule, Restructure \& Rehabilitate your loans,' Official website of Malayan Banking Berhad, http://www.maybank2u.com.my/ $\mathrm{mbb}$ info $/ \mathrm{m} 2 \mathrm{u} /$ public/personalDetail04.do? channelId=\&cntTypeId=1\&cntKey $=$ HL09.09.09\&programId=HI-Highlights\&newsCatId=/mbb/Highlights/2009/09\& bp=1\&chCatId=/mbb/Business, accessed on 5 March 2018.

13 Aznan Hasan, Muhamad Nasir Haron and Mohd Faysal, 'Rescheduling, Refinancing and Restructuring of Islamic Financing Facilities from the Sharī'ah Perspective,' in $10^{\text {th }}$ Muzakarah Cendekiawan Sharī'ah Nusantara (the Regional Sharī'ah Scholar Dialogue), Kuala Lumpur, Malaysia: International Sharīa ah Research Academy for Islamic Finance (ISRA), 1-2 June 2016); Aznan Hasan, Muhamad Nasir Haron, Mohd Faysal Mohammed, and Budeeman Mana, 'Rescheduling and Restructuring of Islamic Financing Facilities: A Sharī'ah Perspective,' 4. 
financing facilities or it may change to other facilities. The process, however, requires additional costs for legal documentation and administration. ${ }^{14}$

Therefore, restructuring of a facility will execute a new contract whilst cancelling out the current regime. It will also prolong the financing tenure and increase the amount payable by the customer. The reason why this new facility is at the expense of extra-legal fees is because it is considered a new contract. ${ }^{15}$ For example, the current contract of muräbahah may change to ijärah, and the instalment of MYR900 is reduced to MYR700, but the repayment duration is extended from 10 years to 20 years.

\section{Reasons for Restructuring of a Financing Facility}

There are some reasons which may lead customers to opt for a restructuring facility. The financial status of a customer may change from time to time, sometimes they may not be able to fulfil their obligations due of unavoidable financial constraints. ${ }^{16}$ In some cases, despite having the means to pay out the repayments, it will be better to change the amount of the contract, according

14 Amirullah Haji Abdullah, and Razli Ramli, Islamic Banking Recovery Process (Kuala Lumpur: Islamic Banking and Finance Institute Malaysia (IBFIM), 2011).

15 Ahmad Sanusi Hussain, Islamic Banking Handbook (Kuala Lumpur: Islamic Bank-Bank Malaysia (IBBM), 2010), 147, http:/www.iefpedia.com/english/ wp-content/uploads/2010/11/Islamic-Banking-Handbook-financial-sector-talentenrichment-programme.pdf, accessed on 28 November 2018.

16 Adam Tijerina, 'Defining The Fine Line Between Debt Consolidation and Debt Restructuring," National Debt Relief, 2016, https://www.nationaldebtrelief.com/ defining-fine-line-debt-consolidation-debt-restructuring/, accessed on 6 March 2018; Aznan Hasan, Muhamad Nasir Haron and Mohd Faysal, 'Rescheduling, Refinancing and Restructuring of Islamic Financing Facilities from the Sharī'ah Perspective,' (2016); Aznan Hasan, Muhamad Nasir Haron, Mohd Faysal Mohammed, and Budeeman Mana, 'Rescheduling and Restructuring of Islamic Financing Facilities: A Sharī'ah Perspective,' 5; Ahmad Sanusi Hussain, Islamic Banking Handbook; Din Che Mat and Mohd Shuhaimi Ismail, 'Rescheduling and Restructuring of Islamic Financing Facilities,' (Seminar on Rescheduling and Restructuring of Islamic Financing Facilities, Seminar Room, IBFIM, Kuala Lumpur, 19 February 2009); 'Abd al-Rahman Al-Ațram, 'Qalb al-Dayn Șuwaruhu wa Aḥkāmuhu wa Badā'iluhu,' in 4th Fiqh Conference for Islamic Finance Institutions, Kuwait, 2011), 233. 
to the prospects' financial strength. ${ }^{17}$ Hence, the change in contract may lead to better financial management. Restructuring of a financing facility will assist customers to avoid any legal repercussions, otherwise it may lead to asset liquidation to settle off the debt. ${ }^{18}$ In order to keep the sustainability of business, restructuring is an alternative to be considered. ${ }^{19}$ When the terms and conditions of a new facility are much better than the current one, customers opt for restructuring. ${ }^{20}$ For customers involved in conventional financing schemes, the restructuring facility can provide them with an option to convert to any Islamic banking financing. Consequently, this facility will allow customers to be released from any rib $\bar{a}$-based financing. ${ }^{21}$

On the other hand, apart from benefiting customers, the financing facility is advantageous for Islamic banks as well. Islamic banks can reduce the numbers on the non-performing lists and keep the performing ones. ${ }^{22}$ By offering this facility, banks can continue financing customers without taking any legal action whilst saving extra costs for litigation and other recovery procedures. ${ }^{23}$ In addition, banks need not impose asset liquidation on customers. ${ }^{24}$

17 Aznan Hasan, Muhamad Nasir Haron and Mohd Faysal, 'Rescheduling, Refinancing and Restructuring of Islamic Financing Facilities from the Sharī'ah Perspective,' (2016); Aznan Hasan, Muhamad Nasir Haron, Mohd Faysal Mohammed, and Budeeman Mana, 'Rescheduling and Restructuring of Islamic Financing Facilities: A Sharī'ah Perspective,' 5; 'Abd al-Rahman Al-Aṭram, 'Qalb al-Dayn Șuwaruhu wa Aḥkāmuhu wa Badā' iluhu,' 233.

18 Ahmad Sanusi Hussain, Islamic Banking Handbook, 106; Din Che Mat and Mohd Shuhaimi Ismail, 'Rescheduling and Restructuring of Islamic Financing Facilities,'.

19 Ahmad Sanusi Hussain, Islamic Banking Handbook, 106; Din Che Mat and Mohd Shuhaimi Ismail, 'Rescheduling and Restructuring of Islamic Financing Facilities,'.

20 Nāṣir Ibn 'Abd al-Raḥmān al-Dawūd, 'I'ādah al-Tamwīl,' in AAOIFI 15th Annual Sharī'ah Boards Conference, Manama, Kingdom of Bahrain: AAOIFI, 2017).

21 Nāṣir Ibn 'Abd al-Raḥmān al-Dawūd, 'I'ādah al-Tamwīl'.

22 Mohd Johan Lee, Islamic Finance Recovery, Rescheduling and Restructuring of Islamic Financing Facilities, 82; Ahmad Sanusi Hussain, Islamic Banking Handbook, 106.

23 Siti Mazlita Yamaludin, 'Recovery Process of Murabahah Financing in Islamic Financial institutions in Malaysia,' (Master's Dissertation, International Islamic University Malaysia, Malaysia, 2014), 65.

24 Din Che Mat and Mohd Shuhaimi Ismail, 'Rescheduling and Restructuring of Islamic Financing Facilities,'. 


\section{Practice of Restructuring of a Financing Facility in Islamic Banking}

Islamic banks must always validate the eligibility of a customer before offering such facility. Therefore, there are some procedures that should be maintained by Islamic banks prior to allowing a customer to apply for the facility. ${ }^{25}$

\section{Step one: Approach}

The facility is not an open product to be promoted hastily to any customers facing financial constraints or unable to commit consistent obligations. Customers themselves should be aware of their financial state and determine whether or not to seek additional financial assistance. Whenever a customer realizes to be in a financial deadlock and requires more financial support to sustain, approaching the bank should be the recommended move, says respondent $\mathrm{A}$. This is the norm and more logical as the customer knows oneself better than any bank. But, if the customer wants to be approached by the bank then it may be delayed, as banks have to check all the customers and determine who is in financial distress unless the customer is listed under the non-performing financing (NPF). Therefore, the former approach that is the customer's initiative is much better than waiting for a call from the bank. ${ }^{26}$

\section{Step two: Eligibility}

Islamic banks cannot offer the facility restructuring to all their customers. For those who are applying, banks will thoroughly check their eligibility. Interested customers should prove that they are facing financial difficulties. If not, then the offering of the facility may lead the customer being indebted for a longer time. In some cases, customers may take advantage of the facility and apply for other financing plans benefiting higher leverage. ${ }^{27}$ While the customers are fulfilling their commitment, banks may offer $i b r \bar{a}^{\prime}$ (rebate) from some of the

25 The procedure of the restructuring of financing facility is adapted from interviews conducted in two Islamic banks in Malaysia.

26 Respondent A (Head of Recovery and Rehabilitation Division, Bank Islam Malaysia Berhad), in an interview with the researcher on 24 October 2018; Respondent B (Head of Shariah Research and Advisory Department, AmBank Islamic Berhad), in an interview with the researcher on 1 August 2018.

27 Respondent A (Head of Recovery and Rehabilitation Division, Bank Islam Malaysia Berhad), in an interview with the researcher on 24 October 2018. 
profit of the facility at the end of the tenure. Therefore, the customer should be eligible to benefit from the facility. ${ }^{28}$

\section{Moratorium for specific occasions}

Both banks, Islamic and conventional, allow moratorium for unavoidable incidences such as natural disasters for example floods and landslides. For debtors who have lost employments or involved in accidents or even death, banks will provide assistance. In such cases, the banks would allow moratorium for six (6) months, where customers need not pay the instalments during the period, but the tenure will be extended six months after that. ${ }^{29}$

\section{Step three: Assessment}

Customer assessment is required to check for creditability. The assessment can range from financial activities of the debtor to include financial activities of family members such as wife, if the husband is the debtor. ${ }^{30}$ To assess a debtor, the bank may ask assistance from the Central Credit Reference Information System $^{31}$ (CCRIS) ${ }^{32}$ for the customer's financial creditability. ${ }^{33}$

28 Respondent A (Head of Recovery and Rehabilitation Division, Bank Islam Malaysia Berhad), in an interview with the researcher on 24 October 2018; Respondent B (Head of Shariah Research and Advisory Department, AmBank Islamic Berhad), in an interview with the researcher on 1 August 2018.

29 Respondent A (Head of Recovery and Rehabilitation Division, Bank Islam Malaysia Berhad), in an interview with the researcher on 24 October 2018; Respondent B (Head of Shariah Research and Advisory Department, AmBank Islamic Berhad), in an interview with the researcher on 1 August 2018.

30 Respondent A (Head of Recovery and Rehabilitation Division, Bank Islam Malaysia Berhad), in an interview with the researcher on 24 October 2018; Respondent B (Head of Shariah Research and Advisory Department, AmBank Islamic Berhad), in an interview with the researcher on 1 August 2018.

31 The CCRIS is a computerized database system of Credit Bureau of BNM, where all the credit-related information of borrowers from financial institutions, are installed. Credit Bureau, 'About the Credit Bureau,' Official website of Credit Bureau, http://creditbureau.bnm.gov.my/creditabout.html, accessed 13 Nov 2018.

32 Credit Bureau, 'Credit Information,' Official website of Credit Bureau, http:// creditbureau.bnm.gov.my/ccris.html, accessed 13 November 2018.

33 Respondent A (Head of Recovery and Rehabilitation Division, Bank Islam Malaysia Berhad), in an interview with the researcher on 24 October 2018. 


\section{Step Four: Final decision}

After being assessed, banks will hand over the application to the top management to have the final verdict whether the customer should be offered the facility or not. Banks will disclose new terms and conditions and other requirements the customer should fulfil to continue the restructuring facility application. Banks, however, have the right to reject the application if they find the customer not eligible.

\section{Step Five: The offer}

Facility restructuring has to undergo strict procedures arranged by banks as it requires cancellation of the current facility and execution of a new contract involving a new selling price and profit rate added with several other legal fees. Nevertheless, the customer may accept or not the offerings in the newly restructured facility. ${ }^{34}$ A Sharī'ah contract of restructuring depends on the nature of the asset as well as the facility, for example, a murābahah contract may change to an ijārah contract or bai'bithaman ajil (BBA) to a murābahah contract.

\section{SHAR $\bar{I}^{\prime} A H$ ISSUES IN RESTRUCTURING OFA FINANCING FACILITY}

Ibn Taymiyyah ${ }^{35}$ introduced the concept of facility restructuring known as qalb al-dayn. The Hanbali school emphasizes on the matter explicitly. Similarly, the Mālikī school used another term which is faskh al-dayn bi al-dayn (Termination of debt with another debt). ${ }^{36}$ Nonetheless, the Hanafì school and Shāfi $\overline{1}$ school did not mention about the matter particularly. The practice of restructuring of a financing facility is a norm applied in Islamic banking institutions, however,

34 Respondent A (Head of Recovery and Rehabilitation Division, Bank Islam Malaysia Berhad), in an interview with the researcher on 24 October 2018.

35 Aḥmad Ibn 'Abd al-Ḥalīm Ibn Taymiyyah, Al-Hisbah fi al-Islām (Beirut: Dār alKutub al-'Ilmiyyah, n.d.), 20; Majmu' al-Fatawa, $3^{\text {rd }}$ ed. (Egypt: Dār al-Wafā, 2005), 28: 74.

36 Muḥammad Ibn 'Abd Allāh al-Kharashī, Sharh al-Kharashī 'alā Mukhtașar alKhalīl (Egypt: Maṭba ah al-Kubrā al-Amīriyyah, $1317 \mathrm{AH}$ ) 2 $2^{\text {nd }}$ ed, 5:76; Shams alDīn Al-Dusūqī, Hāshiyah al-Dusūqī 'alā al-Sharh al-Kabīr (Egypt: 'Īsā al-Bābī al-Ḥalabī wa Shurakā uh, n.d), 3:61; Abū al-Barakāt Aḥmad Ibn Muhammad AlDardīr, Al-Sharḥ al-Ṣagh̄̄r with Ḥāshiyah Al-Ṣāwī, ed. Aḥmad Ibn Muḥammad (Cairo: Dār al-Ma ārif, n.d), 3:96. 
the practice is not free from valid Sharī ah concerns that are to be analyzed deeply.

The rules and issues of qalb al-dayn is discussed in the Hanbali school, especially by Ibn Taymiyyah. ${ }^{37}$ Based on his study, qalb al-dayn is imposing another debt on the same debtor when he is unable to fulfill his current debt, and that can be done through a new contract or demand additional amount from the debtor, while extending time, in allowing him to repay the debt. The facility practiced in Islamic banks is similar to the qalb al-dayn. Therefore, the following Sharī ah issues should be tackled and resolved by the Sharī ah committee before offering such facility to a customer. The issues are as follows:

\section{Qalb al-Dayn on Solvent Debtor (Müsir) and Insolvent Debtor (Mu 'sir)}

Majority of scholars concluded that imposing of qalb al-dayn is not permissible on an insolvent debtor as it is considered as ribā al-jāhiliyyah (interest of the pre-Islamic era) and in this regard, the Qur'ānic verse (2: 280) states that:

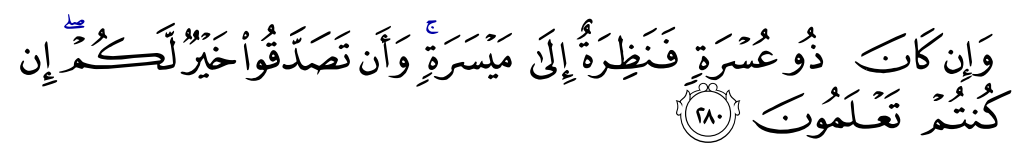

"And if the debtor is in a hard time (has no money), then grant him time till it is easy for him to repay, but if you remit it by way of charity, that is better for you if you did but know".

(Surah al-Baqarah, 2: 280)

The above verse suggests that the creditor should allow ample time to the debtor. The consensus of scholars also proves that qalb al-dayn is prohibited to be applied on an insolvent debtor as cited by Ibn Taymiyyah. ${ }^{38}$ Other contemporary scholars and Islamic institutions of 'Abd al-Bārī Mash'al, ${ }^{39}$

37 Aḥmad Ibn 'Abd al-Ḥal̄̄m Ibn Taymiyyah, Al-Hisbah fi al-'Islām, 20; Majmu` alFatawa, 28:74.

38 Aḥmad Ibn 'Abd al-Halīm Ibn Taymiyyah, Al-Hisbah fi al-'Islām, 20; Majmu' alFatawa, 28:74.

39 'Abd al-Bārī Mash 'al, 'Qaḍāyā Jadaliyyah fi al-Tamwīl al-Islāmiyyah,' (Seminar on Qaḍāyā Jadaliyyah fi al-Tamwīl al-Islāmiyyah, Internantional Islamic University Malaysia, 22 May 2014), https:/www.kantakji.com/financial-engineering/-قضايا aspx, accessed on 3 February 2019. 
International Islamic Fiqh Academy, ${ }^{40}$ and Islamic Fiqh Council ${ }^{41}$ also opined that the application of qalb al-dayn is not allowed whether the debtor is solvent or insolvent. In the case of restructuring a facility, the customer faces difficulty to pay his obligations, and the bank asks him to pay more in a longer period through another contract. The scenario is almost identical to the practice in the pre-Islam era, during that time it was widely practiced: "Increase in asset (which is on the liability of the debtor) for me so that I will increase the period of payment for you". ${ }^{42}$ This practice of restructuring (qalb al-dayn) leads to rib $\bar{a}$, therefore, it should be impermissible. However, there are some arguments among contemporary scholars, where Muhammad 'Alī al-Qarī, ${ }^{43}$ 'Abd Allāh Sulaymān Al-Man̄̄', ${ }^{44}$ and Bahrain Islamic Bank ${ }^{45}$ allow the application of qalb al-dayn on a solvent debtor (müsir) as long as he is able to pay his liabilities without qalb al-dayn and there is no coercion to do so. According to them, this type of qalb al-dayn will not be considered as prohibited. ${ }^{46}$ In addition, they provide some guidelines to be followed prior to offering the facility to a customer.

\section{Refinancing for the Customer (With Difficulties-Ta 'aththur)}

One of the situations that a debtor may face in order to pay his liability, is the liquidation problem due to the decrease in price of the debtor's asset.

40 Resolution no. 158 (7/17), $17^{\text {th }}$ Council of International Islamic Fiqh Academy (IIFA) of Organization of Islamic Cooperation (OIC), Amman (Jordan), 24-28 June 2006.

41 Resolution of 18th Council of Islamic Fiqh Council of Muslim World League, Mecca, 8-12/04/2006. See: http://www.themwl.org/web/فسخ-الدين-في-الدين , accessed 16 February 2019.

42 'Ālā al-Dīn 'Alī Ibn Muhammad al-Khāzin, Tafsīr al-Khāzin - Lubāb al-Tảwūl fì Ma ānō al-Tanzīl (Bayrūt: Dār al-Kutub al-'Ilmiyyah, 2004), 1/296; Maḥmūd Ibn 'Abd Allāh al-Alūsī, Tafsìr al-Alūsì - Rūh al-Ma 'ānī (Bayrūt: Dār 'Ihyā̄' alTurāth al- 'Arabī, n.d.), 4/55; Wizārah al-Awqāf wa al-Shu' ūn al-Islāmiyyah, AlMawsū'ah al-Fiqhiyyah al-Kuwaitiyyah (Kuwait: Wizārah al-Awqāf wa al-Shu'ūn al-Islāmiyyah, 1992), 22/52.

43 Muhammad al- 'Ali al-Qarī, 'Al-Tawarruq Kamā Tajrīh al-Maṣārif,' in al-Majma ' al-Fiqh al-'Islāmī of Muslim World League, Makkah-KSA, 2003, 651.

44 'Abd Allāh Sulaymān al-Man̄̄', 'Hukm Qalb al-Dayn 'Ala Al-Madīn,' in 4th Fiqh Conference for Islamic Finance Institutions, Kuwait, 2011, 219-220.

45 Sharī'ah Board of Bahrain Islamic Bank, 'Fatāwā,' https://bisb.com/media/ document/25-02-20152bisb.pdf, accessed 16 February 2019.

46 Muhammad 'Alī al-Qarī, 'Al-Tawarruq Kamā Tajrīh al-Mașārif', 651; 'Abd Allāh Sulaimān Al-Man̄̄', 'Hukm Qalb al-Dayn 'Ala Al-Madīn', 219-220. 
Subsequently, this will cause the debtor to lose his asset which he should not have if he manages an alternative to pay his liability. Therefore, 'Ișām Khalf al-' Inzi ${ }^{47}$ and Aznan et al. ${ }^{48}$ suggest that facility restructuring should be allowed to sustain the assets. According to these scholars, this situation is between a solvent and insolvent debtor which they call it as ta'aththur. This type of situation is unique to the modern era, vacant from discussions of classical scholars. Therefore, Islamic banks should seek approval from their Shari' ah committee to ensure whether the customer is eligible or not in benefiting the perks of this product.

\section{Conditions Provided by the Scholars for Qalb al-Dayn}

As mentioned earlier, there are some Sharī'ah scholars who allow restructuring of financing facility while providing some restrictions to be followed. Some of the conditions that provided by scholars ('Abd al-Sattār Abū Ghuddah): ${ }^{49}$

a) The new debt contract should not have relation with the existing contract which is facing difficulties.

b) The debtor should face difficulties in liquidation, while not being insolvent.

c) The profits of the new contract should not exceed the profits of the existing contract, to avoid consideration of extra amount as late settlement of the first debt.

d) The conclusion of the new murābahah should not be the purpose to settle the outstanding debt, hence the two contracts should not have any reference to each other.

e) The customer must be allowed to utilize the proceeds of murābahah without any restrictions for a certain period of time.

f) The facility should not be provided many times which will lead the customer to be indebted for longer time.

47 'Ișām Khalf al- 'Inzī, 'Qalb al-Dayn: Tajdīd 'Uqūd al-Murābaḥāt wa al-Wakālāt al-Ististhmāriyyah,' (Paper presented, $4^{\text {th }}$ Fiqh Conference for Islamic Finance Institutions, Kuwait, 2011), 263.

48 Aznan Hasan, Muhamad Nasir Haron, Mohd Faysal Mohammed, and Budeeman Mana, 'Rescheduling and Restructuring of Islamic Financing Facilities: A Sharī' ah Perspective,' 8.

49 'Abd al-Bārī Mash al, 'Qaḍāyā Jadaliyyah fi al-Tamwīl al-Islāmiyyah'; Aznan Hasan, Muhamad Nasir Haron, Mohd Faysal Mohammed, and Budeeman Mana, 'Rescheduling and Restructuring of Islamic Financing Facilities: A Sharī'ah Perspective,' 37. 
The above-mentioned conditions provided by the scholars are to protect Islamic banks from events of non-Sharī'ah compliance. Therefore, Islamic banks should abide by those conditions while providing the facility to their customers.

\section{Settlement of Existing Debt}

From the afore-mentioned conditions and practice of banks, in some conditions, Islamic banks failed to comply as suggested by scholars. For example, Sharī ah scholars suggest that the proceed of the new financing should not require to pay the outstanding of current debt. In the practice of Islamic banks, they do not follow this suggestion. In myriad numbers of cases, the current debt is settled from the proceeds of the new facility before engaging in the new contract. ${ }^{50}$ Respondent B Apparently, the debtor is forced to make payment for the existing contract before proceeding with the new one which is ethically wrong. The use of proceeds from the new contract, should be free of access by the debtor without any restrictions.

\section{Increasing the Amount in New Debt}

Restructuring of a financing facility requires a new contract to be offered. In the new facility, the selling price may go higher than the original selling price that is to settle the existing debt and other payments such as legal documentation. It will result in an increase in the amount of debt liable by the debtor. Since, the debtor has an existing debt (financing) and the restructuring will create another debt on top of it and higher the debt accumulation. ${ }^{51}$ In this regard, Accounting and Auditing Organization for Islamic Financial Institutions (AAOIFI) states that:

50 Respondent B (Head of Shariah Research and Advisory Department, AmBank Islamic Berhad), in an interview with the researcher on 1 August 2018; Nasrun Mohamad@Ghazali, 'Tawarruq in Malaysian Financing System: A Case Study on Commodity Murabahah Product at Maybank Islamic Berhad' (Master's Dissertation, University of Malaya, Kuala Lumpur, 2014), 148.

51 Respondent A (Head of Recovery and Rehabilitation Division, Bank Islam Malaysia Berhad), in an interview with the researcher on 24 October 2018; Respondent B (Head of Shariah Research and Advisory Department, AmBank Islamic Berhad), in an interview with the researcher on 1 August 2018. 
" $5 / 7$ It is not permissible to extend the date of payment of the debt in exchange for an additional payment in case of rescheduling, irrespectively of whether the debtor is solvent or insolvent." ${ }_{52}$

Based on the above-mentioned statement, increasing the amount in the new facility will lead to Sharī'ah non-compliance such as ribā. Therefore, banks should offer the new facility in a way that does not contradict the Sharī ah law.

\section{Single Asset for Two Different Contracts}

The financing product has an underlying asset for example a car, a house or any other assets. The practice of rescheduling does not influence the asset as it changes the installment amount only. Supposedly, there is no issue. However, in practice, the new contract involves changes of the same asset by increasing its original sale price, this will lead to the issue of rollover in murābahah. In this regard, respondent $\mathrm{B}^{53}$ denied this practice being rolling over in murābahah According to respondent $\mathrm{B}$, execution of new 'aqd validates the additional price and it will not lead to any Shari' ah issues as the additional price is not within the same 'aqd (existing contract). However, the rolling over in murābahah, according to Muhammad Ali Shaikh ${ }^{54}$, Ashraf et al..$^{55}$, and Nasrun Mohamad ${ }^{56}$ is considered as non-Sharī'ah compliant. The reason is being non-Sharī'ah compliant is because a new 'aqd (contract) requires actual purchase and sale of assets and transferring the ownership to the buyer wherein the practice of restructuring the commodity is already with the customer. Muhammad Ali Shaikh also added that the practice of rolling over will just defer the problems of the customer and multiply the problems instead of fixing the problems. Similarly, Ashraf et al. believe it as a Sharīah risk which the Islamic banks must avoid. Therefore, to avoid non-compliance of a rollover, Islamic banks should take all the steps which are required to execute a new contract.

52 Accounting and Auditing Organization for Islamic Financial Institutions (AAOIFI), Sharī ah Standards for Islamic Financial Institutions (English version) (Manama, Bahrain: AAOIFI, 2015), 214.

53 Respondent B (Head of Shariah Research and Advisory Department, AmBank Islamic Berhad), in an interview with the researcher on 1 August 2018.

54 Muhammad Ali Shaikh, 'Contemporary Islamic Banking: The Issue of Murābahah,' Islamic Studies, vol. 50, no. 3/4 (2011): 435-448.

55 Muhammad Adeel Ashraf, and Ahcene Lahsasna, 'Proposal for a New Sharīah Risk Rating Approach for Islamic Banks,' ISRA International Journal of Islamic Finance, vol. 9, no. 1 (2017): 87-94.

56 Nasrun Mohamad@Ghazali, 'Tawarruq in Malaysian Financing System: A Case Study on Commodity Murabahah Product at Maybank Islamic Berhad', 148-149. 
The restructuring can also result in an issue regarding the ownership of the asset during the execution of a new contract. If the ownership is already transferred to the customer, then how it should be permissible to engage in another contract when banks have no ownership over it. On the other hand, if the ownership is still under the banks, it will mean that there are two contracts to sell an asset. In other words, it will look like selling an item twice for different prices to the same buyer.

\section{CONCLUSION}

Islamic banks in Malaysia provide restructuring of financing facilities to lessen the burden of the customers in paying back their debt to the respective banks. The facility requires some procedures and steps to follow for the customers including some changes in the existing contract. The paper finds that the practice of restructuring of financing facility in Islamic banking arises several Sharī'ah issues which are not aligned to the Sharī'ah principles. The increase in the new selling price more than the original selling price while allowing the customer to prolong the tenure is a similar concept of qalb al-dayn that most of the scholars have discussed about. And, this practice is considered as nonSharī'ah compliant according to the majority of scholars as it leads to rib $\bar{a}$ al-jāhiliyyah. The execution of a new contract over the existing contract also leads to the issue of transferring ownership of the commodity where in some cases the ownership is already transferred to the customer. Therefore, without concluding the current contract and transferring the ownership back to the Bank will not allow involving in a new contract over the same commodity. In addition, providing the new financing with the condition to settle the current debt is also an unethical action that should be avoided by the Islamic banks.

Therefore, this study recommends that the respective departments of Islamic banks (Sharī'ah research, Recovery and Collection) should be aware of these issues and consult with their Sharī ah committee to confirm that their practice is not leading to non-Sharī'ah compliance issues. Islamic banks may offer only rescheduling of financing facilities in order to avoid those issues instead of restructuring. However, Islamic banks may also cooperate with the customer who is facing difficulties in finding new financing from a third party (another bank) to settle his current hardship. Taking those issues into account and resolving them deliberately may allow Islamic banks to offer customers such a facility. In return, it will help Islamic banks in the continuation of providing Sharī'ah compliant products and keep their reputation as Islamic. For the purpose of future research, extensive research should be carried out by the academician collaborating with the practitioners in ensuring Sharī'ah compliance of all Islamic domestic and international banks. 


\section{REFERENCES}

Accounting and Auditing Organization for Islamic Financial Institutions (AAOIFI), Sharīah Standards for Islamic Financial Institutions (English version). (Manama, Bahrain: AAOIFI, 2015).

Ahmad Sanusi Hussain, Islamic Banking Handbook (Kuala Lumpur: Islamic Bank-Bank Malaysia (IBBM), 2010), http://www.iefpedia.com/english/ wp-content/uploads/2010/11/Islamic-Banking-Handbook-financialsector-talent-enrichment-programme.pdf, accessed 28 November 2018.

Al-Alūsī, Mạ̣mūd Ibn 'Abd Allāh, Tafsīr al-Alūsī - Rūḥ al-Ma ānī (Beirut: Dār 'Iḥyā' al-Turāth al-' Arabī, n.d.)

Amirullah Haji Abdullah, and Razli Ramli, Islamic Banking Recovery Process (Kuala Lumpur: Islamic Banking and Finance Institute Malaysia (IBFIM), 2011).

Al-Ațram, 'Abd al-Raḥmān, 'Qalb al-Dayn Șuwaruhu wa Ạ̣kāmuhu wa Badā' iluhu,' in 4th Fiqh Conference for Islamic Finance Institutions, Kuwait, 21-22 December 2011.

Aznan Hasan, Muhamad Nasir Haron and Mohd Faysal, 'Rescheduling, Refinancing and Restructuring of Islamic Financing Facilities from the Sharīa 'ah Perspective,' in $10^{\text {th }}$ Muzakarah Cendekiawan Sharī ah Nusantara (the Regional Sharī'ah Scholar Dialogue), Kuala Lumpur, Malaysia: International Sharī‘ ah Research Academy for Islamic Finance (ISRA), 2016.

Aznan Hasan, Muhamad Nasir Haron, Mohd Faysal Mohammed, and Budeeman Mana, 'Rescheduling and Restructuring of Islamic Financing Facilities: A Sharī'ah Perspective,' ISRA Research Paper, no. 100 (Malaysia: International Sharī'ah Research Academy of Islamic Finance (ISRA), 2018).

Credit Bureau, 'About the Credit Bureau,' http://creditbureau.bnm.gov.my/ creditabout.html, accessed 13 November 2018.

Credit Bureau, 'Credit Information,' http://creditbureau.bnm.gov.my/ccris. html, accessed 13 November 2018.

Al-Dardīr, Aḥmad Ibn Muhammad, al-Sharḥ al-Șaghīr with Hāshiyah alȘāwī, ed. Aḥmad Ibn Muḥammad (Qāhirah: Dār al-Ma'ārif, n.d)

Al-Dawūd, Nāṣir, 'I'ādah Al-Tamwīl,' in AAOIFI 15th Annual Shari'ah Boards Conference (Manama, Kingdom of Bahrain, 2017). 
Din Che Mat \& Mohd Shuhaimi Ismail, 'Rescheduling and Restructuring of Islamic Financing Facilities,' (Seminar on Rescheduling and Restructuring of Islamic Financing Facilities, Seminar Room, IBFIM, Kuala Lumpur, 19 February 2009).

Al-Dusūqī, Shams al-Dīn, Hāshiyah al-Dusūqī 'alā al-Sharḥ al-Kabīr (Egypt: 'Īsā al-Bābī al-Ḥalabī wa Shurakā' uh, n.d).

Ibn Taymiyyah, Aḥmad, al-Hisbah fì al-Islām (Bayrūt: Dār al-Kutub al'Ilmiyyah, n.d).

Ibn Taymiyyah, Aḥmad, Majmū al-Fatāwā (3 ${ }^{\text {rd }}$ ed). (Miṣr: Dār al-Wafā, 2005).

International Islamic Fiqh Academy (IIFA) of the Organization of Islamic Cooperation (OIC), 'Bay' al-Dayn,' (Resolution no. 158. 7/17), 17 th Council of IIFA of OIC, Amman, Jordan, 2006.

International Monetary Fund (IMF), 'External Debt Statistics: Guide for Compilers and Users,'(USA: IMF, 2014), http://www.tffs.org/pdf/edsg/ ft2014.pdf, accessed 28 November 2018.

Al-'Inzī, 'Ișām Khalf, 'Qalb al-Dayn: Tajdīd 'Uqūd al-Murābahạāt wa alWakālāt al-Ististhmāriyyah,' (Paper presented, 4th Fiqh Conference for Islamic Finance Institutions, Kuwait, 2011).

Islamic Fiqh Council of Muslim World League (MWL), 'Faskh al-Dayn Fī alDayn,' (Resolution no. 3), $18^{\text {th }}$ Council of Islamic Fiqh Council, Mecca, 2006.

Al-Kharashī, Muhammad Ibn 'Abd Allāh, Sharh Al-Kharashī 'alā Mukhtașar Khalīl (Bayrūt: Dār al-Kutub al-'Ilmiyyah, 1997).

Al-Khāzin, 'Ālā al-Dīn 'Alī Ibn Muhammad, Tafsīr al-Khāzin - Lubāb alTảwīl fì Ma 'ānī al-Tanzīl (Bayrūt: Dār al-Kutub al-'Ilmiyyah, 2004).

Al-Man̄̄', 'Abd Allāh Sulaymān, 'Hukm Qalb al-Dayn 'ala al-Madīn,' in 4th Fiqh Conference for Islamic Finance Institutions, Kuwait: Shura Sharia Consultancy, 2011.

Mash'al, 'Abd al-Bārī, 'Qaḍāyā Jadaliyyah fi al-Tamwīl al-Islāmiyyah,' (Seminar on Qaḍāyā Jadaliyyah fi al-Tamwīl al-Islāmiyyah, Internantional Islamic University Malaysia, 22 May 2014), https://www. kantakji.com/financial-engineering/قضايا-جدلية_قلب_الدين_أو_فسخ_الدين-بالآيني. aspx, accessed on 3 February 2019. 
Maybank, '3R Campaign - Reschedule, Restructure \& Rehabilitate your loans,' Official website of Malayan Banking Berhad, http://www. maybank 2 u.com.my/mbb_info/m2u/public/personalDetail04.do? channelId=\&cntTypeId=1\&cntKey $=$ HL 09.09.09\&programId=HIHighlights\&newsCatId=/mbb/Highlights/2009/09\&bp=1\&chCatId=/ mbb/Business, accessed on 5 March 2018.

Mohd Johan Lee, Islamic Finance Recovery, Rescheduling and Restructuring of Islamic Financing Facilities (Selangor: LexisNexis Malaysia Sdn. Bhd., 2016).

Muhammad Adeel Ashraf, and Ahcene Lahsasna. "Proposal for a New Sharī'ah Risk Rating Approach for Islamic Banks." ISRA International Journal of Islamic Finance 9, no. 1 (2017): 87-94.

Muhammad Ali Shaikh, "Contemporary Islamic Banking: The Issue of Murābaḥah.” Islamic Studies 50, no. 3/4 (2011): 435-448.

Nasrun Mohamad@Ghazali, 'Tawarruq in Malaysian financing system: A case study on commodity murabahah product at Maybank Islamic Berhad,' (Master's Dissertation, University of Malaya, Kuala Lumpur, Malaysia, 2014).

Al-Qarī, Muḥammad al- Al̄̄, 'Al-Tawarruq Kamā Tajrīh Al-Mașārif,' in AlMajma' al-Fiqh al-'Islāmī of Muslim World League, Makkah-KSA, 2003.

Ranjit Kumar, Research Methodology: A step-by-step guide for beginners (London: Sage Publications Ltd., 1999).

Sharī'ah Board of Bahrain Islamic Bank, 'Fatāwā,' https://bisb.com/media/ document/25-02-20152bisb.pdf, accessed 16 February 2019.

Siti Mazlita Yamaludin, 'Recovery Process of Murabahah Financing in Islamic Financial institutions in Malaysia,' (Master's Dissertation, International Islamic University Malaysia, Malaysia, 2014).

Tijerina, A., 'Defining The Fine Line Between Debt Consolidation and Debt Restructuring,' National Debt Relief, https://www.nationaldebtrelief. com/defining-fine-line-debt-consolidation-debt-restructuring/, accessed on 6 March 2018.

Wizārah al-Awqāf wa al-Shu' ūn al-Islāmiyyah, al-Mawsū 'ah al-Fiqhiyyah alKuwaytiyyah (Kuwayt: Wizārah al-Awqāf wa al-Shu'ūn al-Islāmiyyah, 1992). 


\section{Interviews}

Respondent A (Head of Recovery and Rehabilitation Division, Bank Islam Malaysia Berhad), in an interview with the researcher on 24 October 2018.

Respondent B (Head of Shariah Research and Advisory Department, AmBank Islamic Berhad), in an interview with the researcher on 1 August 2018. 
Jurnal Syariah, Jil. 28, Bil. 1 (2020) 105-126 